\title{
Compensating Landowners? The State's (Limited) Duty toward Landowners in Delayed Eviction Matters
}

\section{P.E.R}

Pioneer in peer-reviewed,

open access online law publications

Author

Sarah Fick

Affiliation

University olf the Western Cape South Africa

\section{Email sfick@uwc.ac.za}

Date Submission

1 April 2019

Date Revised

1 January 2021

Date Accepted

1 January 2021

Date published

11 February 2021

\section{Editor Prof C Rautenbach}

How to cite this article

Fick S "Compensating Landowners? The State's (Limited)

Duty toward Landowners in

Delayed Eviction Matters" PER / PELJ 2021(24) - DOI

http://dx.doi.org/10.17159/17273781/2021/v24i0a6190

\section{Copyright}

DOI

http://dx.doi.org/10.17159/1727$3781 / 2021 / v 24 i 0 a 6190$

(i)

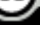

\begin{abstract}
The unlawful occupation of private land creates a tension between the interests of the unlawful occupiers to avoid homelessness and the landowner to regain control of its property. To balance the interests and rights of the occupiers and the landowners, courts have relied on the municipality, due to its constitutional housing duty, to provide the unlawful occupiers with alternative accommodation. The provision of alternative accommodation prevents homelessness, while at the same time allowing the landowner to regain control of its property.

In response to demands by unlawful occupiers that they provide alternative accommodation, municipalities have either failed to cooperate or argued that they are unable to accommodate the unlawful occupiers immediately due to resource constraints. This has led to delays in eviction matters to the detriment of landowners. Only in one delayed eviction matter did the Constitutional Court order relief for the landowner. It ordered the municipality to pay constitutional damages to the landowner. After this order, scholars have advocated for similar relief to be granted in other delayed eviction matters. This article aims to add to that debate, by determining under what circumstances an award of constitutional damages in such matters would be appropriate, just and equitable, as is required of a constitutional remedy.
\end{abstract}

\section{Keywords}

Eviction; constitutional damages; distributive justice. 


\section{Introduction}

The unlawful occupation of land and the eviction of unlawful occupiers are prominent features of post-apartheid South Africa. ${ }^{1}$ It is largely as a result of Apartheid that the large-scale unlawful occupation of land is such a big problem. ${ }^{2}$ The racial segregation during Apartheid forced black people to live in rural areas away from the cities. ${ }^{3}$ These areas were often barren and there was a lack of employment. ${ }^{4}$ After Apartheid came to an end, many black people moved to the cities, seeking employment. ${ }^{5}$ With nowhere to live and limited job opportunities, they often had no choice but to occupy land unlawfully. ${ }^{6}$ More than 20 years into democracy, unlawful land occupations due to poverty still occur. Such unlawful occupations result in eviction applications by landowners. ${ }^{7}$

From a humanitarian perspective, the eviction of desperately poor persons is not desired because it would result in their homelessness. ${ }^{8}$ However, there is also a contrasting interest in granting the eviction order to protect the property rights of the landowner. ${ }^{9}$ This is especially problematic when land is privately owned, since the property interests of private landowners are constitutionally protected. ${ }^{10}$ The unlawful occupation of private land, therefore, creates a tension between the interests of the unlawful occupiers to avoid homelessness and the landowner to regain control of its property. To balance the interests and rights of the occupiers and the landowners, courts have relied on the municipality, due to its constitutional housing

Sarah Fick, Dr. LLB LLM (Stell) PhD (UCT). Senior Lecturer, University of the Western Cape. E-mail: sfick@uwc.ac.za. https://orcid.org/0000-0002-2663-3725.

Chenwi 2008 HR L Rev 107; Wilson 2011 Urban Forum 265-266.

2 Kruger 2014 SALJ 332; Chenwi 2008 HR L Rev 113; President of the Republic of South Africa v Modderklip Boerdery (Pty) Ltd 20055 SA 3 (CC) (hereafter Modderklip) para 36.

3 Chenwi 2008 HR L Rev 113.

4 Chenwi 2008 HRL Rev 113.

5 Mostert "Landlessness, Housing and the Rule of Law" 80; Pienaar Land Reform 663.

$6 \quad$ Chenwi 2008 HR L Rev 113-114; Mostert "Landlessness, Housing and the Rule of Law" 80; Pienaar Land Reform 659-660.

7 Chenwi 2008 HR L Rev 114.

8 Port Elizabeth Municipality v Various Occupiers 20051 SA 217 (CC) (hereafter PE Municipality) para 28; Wilson 2009 SALJ 280; Chenwi 2008 HR L Rev 128.

9 Due to the landowner's constitutional property right, $s 25$ of the Constitution of the Republic of South Africa, 1996 (hereafter the Constitution).

10 Section 25(1) of the Constitution. 
duty, ${ }^{11}$ to provide the unlawful occupiers with alternative accommodation. ${ }^{12}$ The provision of alternative accommodation prevents homelessness, while at the same time allowing the landowner to regain control of its property.

In response to demands by unlawful occupiers that they provide alternative accommodation, municipalities have either failed to cooperate or argued that they are unable to accommodate the unlawful occupiers immediately due to resource constraints. ${ }^{13}$ This has led to delays in eviction matters to the detriment of landowners. ${ }^{14}$ Only in one delayed eviction matter, Modderklip, did the Constitutional Court order relief for the landowner. It ordered the municipality to pay constitutional damages to the landowner for the inability to use its land for the period in which the municipality was unable to accommodate the unlawful occupiers. ${ }^{15}$ After this order, scholars have advocated that similar relief be granted in other delayed eviction matters. ${ }^{16}$ This article aims to add to that debate. The term "delayed eviction matters" is used in this article. The term refers to all matters in which the landowner experiences a court-authorised delay in vindicating its property rights because the unlawful occupiers face homelessness and the state cannot or will not provide them with alternative accommodation in a reasonable time. Such delays can be caused by a postponement of the eviction matter, a suspension of the eviction order or a suspension of the execution of the eviction.

Arguments in favour of awarding constitutional damages to the landowner in delayed eviction matters speak to the alleged violation of the landowner's constitutional right. ${ }^{17}$ Section 38 of the Constitution provides that, when a right in the Bill of Rights has been infringed, a court may grant appropriate

11 The duty on the state to prevent homelessness in eviction and other emergency housing situations was first dealt with in Government of the Republic of South Africa $v$ Grootboom 20011 SA 46 (CC) (hereafter Grootboom) paras 43-44. This duty has been incorporated into the state's Emergency Housing Programme - see DHS National Housing Code Part 3. See the full discussion in section 2 below.

12 In s 26(2) of the Constitution. See for example PE Municipality; Modderklip; City of Johannesburg Metropolitan Municipality v Blue Moonlight Properties 39 (Pty) Ltd 2012 2 SA 104 (CC) (hereafter Blue Moonlight). See also Kruger 2014 SALJ 330.

13 In PE Municipality (para 55) and Modderklip (para 31) the municpality failed to cooperate. In Blue Moonlight (para 68) and City of Johannesburg Metropolitan Municipality $v$ Hlophe 20152 All SA 251 (SCA) (para 6) the municipality argued that it lacked the available resources.

14 In PE Municipality the court denied the eviction order; in Modderklip the eviction was delayed indefinitely until the state could provide alternative accommodation; and in Blue Moonlight the eviction was delayed for six years due to postponements because the state could not provide alternative accommodation.

15 Modderklip para 68.

16 See for example Van der Walt Constitutional Property Law 278-279; Kruger 2014 SALJ 328-364; Kotzé Effective Relief Regarding Residential Property 104-146.

17 Kruger 2014 SALJ 330; Van der Walt Constitutional Property Law 278; Kotzé Effective Relief Regarding Residential Property 10; Viljoen 2015 SAPL 47; Strydom and Viljoen 2014 PELJ 1208. 
relief. Section 172(1)(b) provides that, in deciding a constitutional matter, a court may make any order that is just and equitable. Read together, the Constitution requires relief that is appropriate, just and equitable. ${ }^{18}$ In Fose $v$ Minister of Safety and Security (hereafter Fose), ${ }^{19}$ the Constitutional Court found that there is "no reason in principle why 'appropriate relief' should not include an award of damages."20

The purpose of this article is to determine under what circumstances an award of constitutional damages would be appropriate, just and equitable, as is required of a constitutional remedy. ${ }^{21}$ First, it aims to determine when it would be appropriate to award constitutional damages in delayed eviction matters. Second, it aims to establish when such an award would be just and equitable.

An overarching argument in this article is that an award of constitutional damages together with the staying of the eviction in delayed eviction matters effectively amounts to the state's preventing the homelessness of the unlawful occupiers. Such a remedy, therefore, ensures that the state fulfils its housing duty toward the unlawful occupiers. This article considers the effect of this argument on the question of whether an award of constitutional damages would be appropriate, just and equitable in delayed eviction matters. It finds that an award of constitutional damages would usually not be appropriate relief. Moreover, if an award of constitutional damages is to be found appropriate, the principles of distributive justice must be applied in determining the compensation amount to ensure that the relief is just and equitable.

To reach these conclusions, this article first explains the law regarding eviction in South Africa and how it relates to delayed eviction matters. Second, it examines whether such delays amount to violations of the landowners' rights. Third, the article explains why it can be said that an award of constitutional damages in delayed eviction matters amounts to the provision of housing to the unlawful occupiers by the state and why this fact is relevant to a determination of relief for the landowner. The article then considers whether and under what circumstances an award of constitutional damages as relief for the landowner would be appropriate, just and equitable.

18 Roach and Budlender 2005 SALJ 326 fn 7; Mbazira Litigating Socio-economic Rights 7.

19 Fose v Minister of Safety and Security 19973 SA 786 (CC) (hereafter Fose).

20 Fose para 60.

21 Sections 38 and 172 of the Constitution. 


\section{Delays in eviction matters}

Post-Apartheid evictions are governed by section 26(3) of the Constitution. It prohibits evictions (from homes) that are arbitrary or done without the authority of a court order. A court may grant an eviction order only if it is just and equitable, ${ }^{22}$ considering all of the relevant circumstances. To give effect to section 26(3) of the Constitution, the Prevention of Illegal Eviction from and Unlawful Occupation of Land Act 19 of 1998 (hereafter PIE) was enacted. ${ }^{23}$ It sets out the procedural and substantive requirements for obtaining an eviction order in line with the Constitution. ${ }^{24}$

As the title suggests, PIE protects not only unlawful occupiers but also private landowners whose properties have been unlawfully occupied. This is, in part, because landowners have a constitutional property right, in terms of section 25 of the Constitution. Section 25(1) prohibits the arbitrary deprivation of property and requires deprivation to be in terms of a law of general application. Also, section 25(2) protects landowners against expropriations that are not in terms of a law of general application and not in the public interests or for a public purpose. Expropriations must receive just and equitable compensation. ${ }^{25}$

Section 25 is relevant when the eviction application is made by a private landowner. In such a situation, the rights of the landowner and those of the unlawful occupiers conflict. ${ }^{26}$ This conflict may seem unresolvable when the unlawful occupiers occupied the land out of desperation and have nowhere else to live. ${ }^{27}$ An eviction would leave them homeless. When the court is considering the relevant circumstances, ${ }^{28}$ it may come to the conclusion that, on the one hand, an eviction order would not be just and equitable

22 Section 172(1)(b) of the Constitution.

23 Kruger 2014 SALJ 330.

24 Chenwi 2008 HR L Rev 117.

25 Section 25(2) of the Constitution, as determined in terms of $s$ 25(3).

26 Chenwi 2008 HR L Rev 134; Muller and Liebenberg 2013 SAJHR 555; Van der Walt 2005 SAJHR 150.

27 As was the case in PE Municipality para 59; Blue Moonlight para 39; Modderklip para 43. See also City of Johannesburg v Changing Tides 74 (Pty) Ltd 20126 SA 294 (SCA) (hereafter Changing Tides) para 10; Occupiers of Erven 87 and 88 Berea $v$ De Wet 20175 SA 346 (CC) (hereafter Berea) para 57; Occupiers of 51 Olivia Road, Berea Township and 197 Main Street Johannesburg v City of Johannesburg 20083 SA 208 (CC) (hereafter Olivia Road) para 7.

28 These include: the rights and needs of the elderly,children, disabled persons and households headed by women; the availability of alternative accommodation and whether the state is able to provide such; the circumstances under which the unlawful occupier occupied the land and erected the building or structure; and the period the unlawful occupier and his or her family have resided on the land in question. See $S$ 4(6), 4(7) and 6(3) of Prevention of Illegal Evictions from and Unlawful Occupation of Land Act 19 of 1998 (hereafter PIE). Also see the discussion of "relevant circumstances" in PE Municipality paras 24-32. 
toward the unlawful occupiers because they will be homeless, ${ }^{29}$ yet on the other hand a denial of the eviction order would not be just and equitable toward the landowner because the landowner would be unable to vindicate its property rights. ${ }^{30}$

To resolve this tension the courts have turned to the state and ordered it to provide alternative accommodation to the unlawful occupiers. ${ }^{31}$ Such an order is grounded on the state's housing duty. ${ }^{32}$ Section 7(2) of the Constitution requires the state to respect, protect, promote and fulfil the rights in the Bill of Rights. This includes section 26(1) of the Constitution, which provides that everyone has a right to access to adequate housing. Section 26(2) confirms the duty on the state to realise this right but also places some internal limitations on the state's duty. The state's measures for fulfilment need only meet the standard of reasonableness. ${ }^{33}$ Moreover, the state needs to provide access to adequate housing only progressively and within its available resources.

In Grootboom the Constitutional Court interpreted this duty on the state to include a duty to implement a short-term housing plan for emergency housing situations such as evictions. ${ }^{34}$ In response, the state adopted an Emergency Housing Programme (hereafter the EHP). ${ }^{35}$ In terms of this programme, the municipality should identify a potential emergency housing situation, ${ }^{36}$ such as an unlawful occupation that may leave the occupiers homeless. ${ }^{37}$ It should then engage with the unlawful occupiers and plan to find a solution to their housing emergency. This duty of meaningful engagement is, to some extent, recommended in PIE, and was subsequently made a requirement by the Constitutional Court. ${ }^{38}$ It involves "a two-way process" in which the municipality and the unlawful occupiers talk to each other to find a mutually beneficial solution. ${ }^{39}$

29 Generally an eviction that leaves the occupiers homeless would not be just and equitable toward them - see PE Municipality para 28; Berea para 57; Blue Moonlight para 92; Changing Tides para 15. See also Viljoen 2015 SAPL 49; Chenwi 2008 HR L Rev 128.

$30 \quad$ See Changing Tides paras 12, 19.

31 Strydom and Viljoen 2014 PELJ 1215.

32 This is based on Grootboom para 95.

33 Section 26(2) of the Constitution; Grootboom para 41.

34 Grootboom paras 43, 56.

35 Wilson 2009 SALJ 275; DHS National Housing Code Part 3.

36 DHS National Housing Code Part 331.

37 DHS National Housing Code Part 315.

38 Section 7 of PIE. The Constitutional Court first stressed the importance of engagement in PE Municipality para 61, referred to in Chenwi $2008 H R L$ Rev 126. In Olivia Road para 13, engagement was confirmed as a requirement. Also see Viljoen 2015 SAPL 51; Chenwi 2009 CCR 380; Wilson 2009 SALJ 287-288. For more on engagement, see generally Muller 2011 Stell LR 742-758.

39 Olivia Road para 14. 
After Grootboom, courts have required the state to be joined to private evictions and have requested it to report on whether it can provide alternative accommodation to unlawful occupiers facing homelessness. ${ }^{40}$ While the state has a short-term housing duty in emergencies, this housing duty is still subject to the internal limitations of section 26(2) of the Constitution. Seemingly in line with this limitation, the state has reported that, due to its limited resources, it is unable to provide alternative accommodation immediately. ${ }^{41}$

The court seems to approach an argument by the state that it does not have the available resources immediately to provide suitable alternative accommodation variously, based on the identity of the applicant. In PE Municipality the Constitutional Court denied the eviction order. The eviction application had been brought by the state and it was unable/unwilling to provide suitable alternative accommodation. ${ }^{42}$ In Blue Moonlight the eviction application was brought by the private landowner. The Constitutional Court delayed the eviction matter until the state was able to provide alternative accommodation within the limits of its available resources. ${ }^{43}$ This inevitably placed a burdensome duty on the private landowner to endure continued unlawful occupation of its land until the state was able to fulfil its duty.

Mostly, courts have failed to award any form of relief to the landowners while they await the execution of the eviction order. This has been justified on the basis that the right to property is not absolute and that the landowner can be expected to endure a delay in regaining the use of its rights. ${ }^{44}$ This is supported by the fact that in some cases the landowner knew about the unlawful occupation when acquiring the property or did not require the occupied property for housing purposes. ${ }^{45}$ There was, however, one Constitutional Court case in which the court granted relief to the landowner for such a delay.

Modderklip involved the unlawful occupation of farmland. ${ }^{46}$ The landowner requested the state's assistance to no avail. ${ }^{47}$ Six months after the initial

40 The court made such a decision for the first time in Sailing Queen Investments $v$ The Occupants La Colleen Court 20086 BCLR 666 (W) para 18. Also see Strydom and Viljoen 2014 PELJ 1213; Wilson 2009 SALJ 283. On joinder in general, see Muller and Liebenberg 2013 SAJHR 554-570. On the duty to report, see Wilson 2009 SALJ 285-287.

$41 \quad$ See for example, Blue Moonlight para 70.

42 This was the outcome of the PE Municipality case. Also see Kruger 2014 SALJ 332333.

43 In Blue Moonlight the eviction was postponed pending the provision of alternative accommodation to the unlawful occupiers; Strydom and Viljoen 2014 PELJ 1223; Viljoen 2015 SAPL 48-49.

44 See, for example, Blue Moonlight para 40.

45 As was the case in Blue Moonlight, see para 40.

46 Modderklip para 1.

47 Modderklip para 6. 
unlawful occupations started, realising that the state was not going to get involved, the landowner sought an eviction order. ${ }^{48}$ The court granted the eviction order but by the time the order was to be executed, the unlawful occupation had grown to 40000 people. ${ }^{49}$ The sheriff informed the landowner that, due to the size of the occupation, it would need to obtain private assistance. ${ }^{50}$ This would cost the landowner R 1.8 million, more than the value of the occupied land. ${ }^{51}$

Consequently, the landowner applied to the court for an order requiring the state to execute the eviction order. ${ }^{52}$ The High Court and the Supreme Court of Appeal (hereafter the SCA), similarly, ${ }^{53}$ found that the unlawful occupation violated the landowner's constitutional right to property in terms of section 25(1) of the Constitution. ${ }^{54}$ In addition, it was found that the state had violated the unlawful occupiers' right to access to adequate housing by not fulfilling its short-term housing duty toward them and providing them with alternative accommodation. ${ }^{55}$ This finding was made without considering the effect of the internal limitation found in section 26(2), which requires fulfilment of the right to access to adequate housing only to the extent that the state has available resources. Furthermore, the court found that the state's failure to provide alternative accommodation or to purchase the property from the landowner had resulted in their continued unlawful occupation of the property and, therefore, in a continued violation of the landowner's right to property, this time presumably by the state. ${ }^{56}$ Therefore, by failing to expropriate/purchase the property or to provide alternative accommodation, the state was not only violating the unlawful occupiers' right to housing but also the landowner's right to property. As a result, the court ordered the state to pay constitutional damages to the landowner for the continued violation of its rights. ${ }^{57}$ The amount of damages was to be determined according to the amount that the property would have been expropriated for had the state expropriated the land. ${ }^{58}$

The court's finding that the state's failure to purchase the land or provide alternative accommodation amounted to a violation of section 26(2) is problematic. It was made without a determination regarding whether the state had the resources to purchase the property or provide alternative

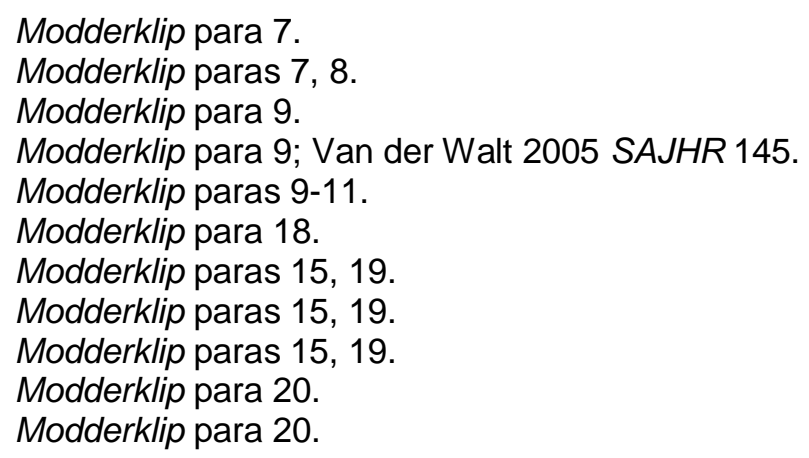


accommodation. The court seemed to justify its failure to consider the state's available resources by suggesting that the state should have done more during the initial unlawful occupation and was somehow responsible for the subsequent growth of the occupation. ${ }^{59}$ However, factual causation is not shown.

The Constitutional Court granted the same relief but on different grounds. ${ }^{60}$ It based its finding on the right to access to courts and the fact that the state is responsible for ensuring that court orders be executed. ${ }^{61}$ In failing to ensure this execution, the state violated the landowner's right to access to courts and, as relief, must compensate the landowner. ${ }^{62}$ The court's reluctance to decide on whether sections 25 and 26 were violated is unfortunate.

What must be determined is whether an award of constitutional damages in favour of the landowner should be limited to Modderklip-type situations. That is, matters in which an eviction order had already been granted and cannot be executed, thereby violating section 34 of the Constitution. In other words, it must be decided whether constitutional damages can be awarded as a remedy in delayed eviction matters where the violation of sections 25 and 26 is alleged and not that of section $34 .{ }^{63}$ It has been argued that the application of the Modderklip judgment is limited to matters where there is an alleged violation of section $34{ }^{64}$ The following section considers whether it could be argued that a delayed eviction matter amounts to a violation of section 25, whereas the subsequent section considers whether it could be argued that constitutional damages in delayed evictions are awarded to give effect to section 26 of the Constitution.

\section{Rights violation}

Constitutional damages are likely to be granted only if it is found that a right protected by the Bill of Rights has been violated. ${ }^{65}$ The right that is potentially violated in delayed eviction matters is the landowner's property right under section 25(1) of the Constitution. Section 25(1) is violated if a

$59 \quad$ Modderklip paras 33, 53.

$60 \quad$ Modderklip para 65.

61 Modderklip para 50. The right to access to courts is entrenched in s 34 of the Constitution.

62 Modderklip para 65.

63 As explained, in this article the term "delayed eviction matters" is used. This term refers to all matters in which the landowner experiences a court-authorised delay in vindicating its property rights due to the fact that the unlawful occupiers face homelessness and the state cannot or will not provide them with alternative accommodation within a reasonable time. Such delays can be caused by a postponement of the eviction matter, a suspension of the eviction order or a suspension of the execution of the eviction.

64 Kruger 2014 SALJ 340-341.

65 Fose para 60. 
deprivation is not authorised by law or is arbitrary. As a threshold requirement, it must be determined whether a delay in an eviction matter could constitute a deprivation. A delay in an eviction matter would have the effect that the land remains unlawfully occupied. That an unlawful occupation amounts to deprivation is not contentious. ${ }^{66}$ It meets even the strict definition of deprivation formulated in Mkontwana $v$ Nelson Mandela Metropolitan Municipality (hereafter Mkontwana). ${ }^{67}$ In this matter the Constitutional Court defined deprivation as "at the very least, substantial interference or limitation that goes beyond the normal restrictions on property use or enjoyment found in an open and democratic society."68 The unlawful occupation of land complies with this strict definition of deprivation. ${ }^{69}$ The interference is so substantial that the owners are unable to use the occupied parts of their properties whatsoever.

Nevertheless, all deprivations are not unconstitutional; only those that are not done in terms of a law of general application or are arbitrary. ${ }^{70}$ It can be argued that evictions that are delayed by courts amount to deprivations in terms of PIE, a law of general application. ${ }^{71}$ That is because, as suggested in Blue Moonlight, the procedural and substantive requirements in PIE allow courts to delay eviction matters, preventing the landowner from swiftly regaining possession of his property. ${ }^{72}$ In other words, PIE authorises the delay.

Finally, one would have to determine whether delays in eviction matters amount to deprivations that are arbitrary. The primary argument has been that a lengthy delay may be arbitrary because the landowner is required to perform the state's housing duty. ${ }^{73}$ Only in situations where there is justification for placing such a housing duty on the landowner has it been argued that a lengthy (or even indefinite) delay would not be arbitrary. ${ }^{74}$

An unusually long deprivation, without justification for placing the housing duty on the landowner, would be arbitrary. This is in line with the test for

$66 \quad$ Blue Moonlight para 37.

67 Mkontwana $v$ Nelson Mandela Metropolitan Municipality 20051 SA 530 (CC) (hereafter Mkonwtana). See Kruger 2014 SALJ 337. As opposed to the more lenient definition in First National Bank of SA Limited t/a Wesbank v Commissioner for the South African Revenue Services; First National Bank of SA Limited ta Wesbank v Minister of Finance 20024 SA 768 (CC) (hereafter FNB).

68 Mkontwana para 32.

69 Kruger 2014 SALJ 337.

70 Section 25(1) of the Constitution.

71 Kruger 2014 SALJ 338; Blue Moonlight para 40.

72 Blue Moonlight para 40. Here the court found that "An owner's right to use and enjoy property at common law can be limited in the process of the justice and equity enquiry mandated by PIE".

73 Kruger 2014 SALJ 340; Strydom and Viljoen 2014 PELJ 1229; Kotzé Effective Relief Regarding Residential Property para 44; Blue Moonlight para 100.

74 Kruger 2014 SALJ 344. 
arbitrariness. In terms of the test, courts have to consider whether there is sufficient reason for the deprivation ${ }^{75}$ - in other words, whether there was justification for the deprivation. To determine whether there is justification for the deprivation a court must evaluate "the relationship between means employed, namely the deprivation in question, and ends sought to be achieved, namely the purpose of the law in question." This involves considering a "complexity of relationships":

(c) In evaluating the deprivation in question, regard must be had to the relationship between the purpose of the deprivation and the person whose property is affected.

(d) In addition, regard must be had to the relationship between the purpose of the deprivation and the nature of the property as well as the extent of the deprivation in respect of such property.

(e) Generally speaking, where the property in question is ownership of land or a corporeal moveable, a more compelling purpose will have to be established in order for the depriving law to constitute sufficient reason for the deprivation, than in the case when the property is something different, and the property right something less extensive. This judgment is not concerned at all with incorporeal property.

(f) Generally speaking, when the deprivation in question embraces all the incidents of ownership, the purpose for the deprivation will have to be more compelling than when the deprivation embraces only some incidents of ownership and those incidents only partially.

(g) Depending on such interplay between variable means and ends, the nature of the property in question and the extent of its deprivation, there may be circumstances when sufficient reason is established by, in effect, no more than a mere rational relationship between means and ends; in others this might only be established by a proportionality evaluation closer to that required by section 36(1) of the Constitution.

(h) Whether there is sufficient reason to warrant the deprivation is a matter to be decided on all the relevant facts of each particular case, always bearing in mind that the enquiry is concerned with "arbitrary" in relation to the deprivation of property under section 25 .

Paragraphs (c) and (d) above indicate the types of relationships that the court will consider in evaluating the relationship between the means and the end: the relationship between the purpose of the deprivation and the person whose property is affected, as well as the relationship between the purpose and the nature of the property and the extent of the deprivation. When considering paragraphs (e) to $(\mathrm{g})$, it is evident that paragraph (d) is aimed at determining the level of scrutiny to be applied when evaluating the relationship between the means and the end. The paragraphs explain that the nature of the property and the extent of the deprivation affect how compelling the reason for the deprivation must be. When the nature of the property is the ownership of land or when the deprivation embraces all

$75 \quad$ FNB para 100. 
incidents of ownership, sufficient reason needs to be established by a proportionality analysis.

In applying this test, the "purpose of the deprivation", in situations where occupiers face homelessness, is to prevent such homelessness. The means of achieving this end is through deprivation (by delaying the eviction). To determine how the relationship between the means and the end must be evaluated, one must determine the nature of the property and the extent of the deprivation. With unlawful occupations, the nature of the property is ownership of land and the extent of the deprivation is that it embraces all incidents of ownership. Hence, a compelling reason for the deprivation is required and the means must be proportional to the end.

In determining the relationship between the means and the ends, $F N B$, in (c) above, urges one to consider the relationship between the purpose of the deprivation and the person whose property is affected. The "person whose property is affected" is the landowner. In terms of this test, therefore, a link between the occupiers' housing need (the purpose of the deprivation) and the specific landowner may justify a lengthy deprivation. Thus, to avoid arbitrariness there must be a reason for burdening the specific landowner with the housing need of the specific occupiers - in other words, a justification for placing the duty to house them on the landowner. This justification must be compelling and a proportionality evaluation should be undertaken.

Such a justification would exist if the landowner reconciled himself with the possibility of a lengthy unlawful occupation by the occupiers due to their housing need. This was the case in Blue Moonlight, where the landowner knowingly bought property that was unlawfully occupied by desperately poor people. ${ }^{76}$ Another potential justification would be where the landowner has a maintenance duty toward the unlawful occupiers. This was the case in Arendse $v$ Arendse ${ }^{77}$ where the landowner was the father of some of the persons facing eviction.

When there is no relationship between the purpose and the owner, the deprivation is more likely to be arbitrary. This is because there would be no justification for burdening that specific owner. As stated in $F N B$, the relationship between the purpose and the owner influences the relationship between the means and the end. When there is no justification for depriving this specific owner, the means may not be proportional to the end. The only justification for burdening the specific owner could be that the land is

76 The abandonment or non-use of one's property may also indicate that one has reconciled oneself to the possibility of unlawful occupation, as in PE Municipality paras 50, 51, 59.

77 Arendse v Arendse 20133 SA 347 (WCC). 
occupied by relatively settled persons. However, if, as in Modderklip, the landowner is not to blame for the occupation, this reason would probably not be compelling enough.

Kruger contends that usually, in eviction matters, no such relationship exists between the reason and the landowner and there is no justification for placing a housing duty on the landowner. ${ }^{78}$ This would mean that most lengthy delays in eviction matters would amount to arbitrary deprivations.

As explained above, special circumstances may justify placing the state's housing duty on the private landowner, in turn justifying some delay in eviction matters. Nevertheless, most of these circumstances would not justify an indefinite delay in a private eviction matter. ${ }^{79}$ It would probably justify only a temporary albeit lengthy delay, such as the six-year delay in Blue Moonlight. ${ }^{80}$ Accordingly, an indefinite delay in a private eviction is likely to be arbitrary. Likewise, a lengthy temporary delay would be arbitrary if there is no justification for placing the state's housing duty on the private landowner for that period. ${ }^{81}$ Such deprivations would therefore amount to violations of the landowner's right to property in terms of section 25(1) of the Constitution.

The question is, however, why this violation is ascribed to the state when the state is not the entity occupying the property. It can be argued that deprivations ordered by the court in terms of PIE are perpetrated by the state because the state enacted the legislation authorising the delay. ${ }^{82}$ Tushnet explains that:83

... the people or corporations exercising "private" power are actually exercising power conferred on them by laws creating and regulating market behavior.

Moreover, it a branch of government (the court) that orders the delay. Accordingly, the state is responsible for any limitations in terms PIE.

\footnotetext{
78 Kruger 2014 SALJ 344.

79 Blue Moonlight para 40. Except perhaps, as mentioned above, an eviction where the landowner has a maintenace duty toward the occupiers, as in Arendse $v$ Arendse 2013 3 SA 347 (WCC).

80 Kruger 2014 SALJ 335.

81 This is confirmed by the fact that temporary deprivations are possible: Mkontwana para 45.

82 For the idea that the state is liable for limitations done in terms of legislation, Tushnet 2003 ICON 79; Van der Walt 2005 SAJHR 152-153 fn 37. Kruger explains that this delay is different from a delay prior to court involvement since such a delay would not be authorised by PIE: Kruger 2014 SALJ 337.

83 Tushnet 2003 ICON 79.
} 
Delayed eviction matters can therefore in some situations be considered a violation of the landowner's property right by the state. ${ }^{84}$ This would be the case if there is no justification for placing a housing duty on the landowner, such as when it is not to blame for the unlawful occupation, does not have a maintenance duty toward the landowner and did not buy it knowing that the property was unlawfully occupied. The Constitution requires a court to grant the landowner appropriate, just and equitable relief for the violation. Before examining when the awarding of constitutional damages under such circumstances would be appropriate, just and equitable, the following section explains that the relief granted in delayed eviction matters is also aimed at giving effect to the rights of the unlawful occupiers. This fact is relevant to the subsequent determination regarding whether constitutional damages would provide appropriate, just and equitable relief in delayed eviction matters.

\section{Constitutional damages as a fulfilment of the state's housing duty}

An award of constitutional damages is considered relief for the violation of the landowner's rights. The purpose of this section is to show that this is not the sole aim of such relief. If remedying the violation of the landowner's property right was the sole purpose of the relief, constitutional damages would not be the preferred remedy because the landowner would not regain control of its property (which is what the landowner desires). Instead, the most appropriate relief would be an eviction order. ${ }^{85}$ The reason why an eviction order is not granted is because an award of constitutional damages aims to give effect to another right simultaneously, the right of the unlawful occupiers to access to adequate housing. ${ }^{86}$ This conclusion is explained below. As will be shown, it is necessary to take this conclusion into account when determining whether an award of constitutional damages would be appropriate, just and equitable.

As explained, ${ }^{87}$ the state has a housing duty in terms of section 26(2) of the Constitution. This duty has been interpreted to include the provision of shortterm housing. ${ }^{88}$ This means that the state has a duty toward persons in

84 This was found in the Supreme Court of Appeal decision of Modderklip. See Modderklip para 19.

85 This can be classified as a remedy based on a "property rule" as opposed to a "liability rule". Injunctions (like evictions) are remedies based on property rules and compensation for damages is ordered as a remedy for the violation of a liability rule. For a discussion on the difference between property and liability rules, see Calabresi and Melamed 1972 Harv L Rev 1089-1128.

86 Constitutional damages can be classified as a remedy based on a "liability rule"; see the previous footnote.

87 See the discussion in section 2 above.

88 Grootboom paras 43, 56. 
emergency housing situations to provide them with (at least temporary) housing. ${ }^{89}$ The duty is limited by the extent of the state's available resources, however. ${ }^{90}$

An eviction where the occupiers face homelessness has been identified as an emergency housing situation. ${ }^{91}$ To fulfil its short-term housing duty, the state must engage with the unlawful occupiers to find a solution to their housing situation. ${ }^{92}$ Potential solutions include the state providing alternative land for the occupiers to live on and the state renting, purchasing or (temporarily) expropriating the currently occupied land so that the occupiers can continue occupying the land without the risk of eviction. ${ }^{93}$

Nevertheless, the state does not always engage with the unlawful occupiers before an eviction application nor does it always endeavour to solve their emergency housing situation. ${ }^{94}$ In such situations, where the unlawful occupiers face homelessness and the land is privately owned, a tension exists between the interests of the unlawful occupiers and the landowners. ${ }^{95}$ On the one hand, an eviction would not be just and equitable toward the unlawful occupiers and, on the other hand, a denial or unreasonably long

89 Grootboom paras 52, 65.

90 Section 26(2) of the Constitution. Also see Blue Moonlight para 69.

91 Para 2.3.1(c) of the EHP (DHS National Housing Code Part 3). This correlates with eviction cases in which the state's short-term housing duty has been relied upon. See, for example, Blue Moonlight, Changing Tides, Occupiers of Skurweplaas $353 \mathrm{JR} v$ PPC Aggregate Quarries (Pty) Ltd 20124 BCLR 382 (CC) (hereafter Skurweplaas), Modderklip.

92 See the discussion in section 2 above. In Olivia Road para 13, engagement was confirmed as a requirement. Also see Viljoen 2015 SAPL 51; Chenwi 2009 CCR 380; Wilson 2009 SALJ 287-288. For more on engagement, see generally Muller 2011 Stell LR 742-758.

93 These solutions are proposed by the author. The provision of alternative accommodation has received the most attention in courts: see Blue Moonlight, PE Municipality, Changing Tides, Olivia Road, Skurweplaas. The purchasing or expropriation of currently occupied land received attention in Modderklip. More recently, the City of Cape Town was ordered by agreement to purchase unlawfully occupied private land, in Coppermoon Trading 203 (Pty) Ltd $v$ The Persons whose Identities are to the Applicant Unknown and Unlawfully Occupy Remainder Erf 148, Phillipi, Cape Town (SCA) (unreported) case number 653/18, 701/18, 821/18, 708/18 of 4 March 2020.

94 A number of eviction matters before the Constitutional Court illustrate the state's faillure to engage prior to the application and to try to solve the housing situation. See PE Municipality para 55, Blue Moonlight paras 78-79, Modderklip para 31.

95 Changing Tides para 18 identifies this tension. Also see Blue Moonlight para 34. Wilson calls this a "stalemate" situation. See Wilson 2009 SALJ 282. 
delay of the eviction would not be just and equitable toward the landowners. ${ }^{96}$ This tension may seem unresolvable. ${ }^{97}$

However, courts have relied on the state's short-term housing duty to resolve the tension. Courts have ordered the state to provide unlawful occupiers with alternative accommodation. ${ }^{98}$ Without reliance on the state's housing duty, there would have been no justification for placing the duty to resolve the tension on the state. While it does have a duty to protect the landowner's property right, the fulfilment of this duty would require an eviction order alone. The condition to provide alternative accommodation is a fulfilment of the state's housing duty toward the unlawful occupiers. This has been acknowledged by the Constitutional Court. ${ }^{99}$

Similarly, the payment of constitutional damages in delayed eviction matters does not only remedy the right-violation of the landowner but also fulfils the state's short-term housing duty. This is because the compensation order is a compromise, it is aimed at giving relief to the landowner but also at ensuring the occupiers are not evicted and become homeless. The payment of compensation justifies the stay of eviction, which prevents the homelessness of the occupiers. As indicated, a remedy aimed solely at providing relief for the landowner would be an eviction order. The alternative remedy of constitutional damages is used to cater for the interests of the occupiers. There must be justification for holding the state responsible for providing this relief to the occupiers. This justification is the state's shortterm housing duty.

A compensation order (which allows for a stay of eviction) solves the occupiers' housing emergency by ensuring that they have land from which they will not be evicted. It is akin to the options open to the state for fulfilling its short-term housing duty by preventing the eviction: rental, purchase or (temporary) expropriation. ${ }^{100}$ Concern for the separation of powers is a

96 Generally an eviction that leaves the occupiers homeless would not be just and equitable toward them. See PE Municipality para 28; Berea para 57; Blue Moonlight para 92; Changing Tides para 15. Also see Viljoen 2015 SAPL 49; Chenwi 2008 HR $L \operatorname{Rev} 128$. For the argument that an unreasonable delay would not be just and equitable toward the landowner, see Changing Tides paras 12, 19.

97 Hence, Wilson's reference to it as a "stalemate" situation. See Wilson 2009 SALJ 282.

98 See, for example, Blue Moonlight, Changing Tides, Skurweplaas.

99 See, for example, Blue Moonlight paras 86-87.

100 As was recently found in Coppermoon Trading 203 (Pty) Ltd v The Persons whose Identities are to the Applicant Unknown and Unlawfully Occupy Remainder Erf 148, Phillipi, Cape Town (SCA) (unreported) case number 653/18, 701/18, 821/18, 708/18 of 4 March 2020. Also see Viljoen's discussion of the possibilty of the state's using its power of temporary expropriation to fulfil its housing duties, in Viljoen 2014 TSAR (Part 1) 359-376 and Viljoen 2014 TSAR (Part 2) 520-535 - see especially 534. Viljoen's focus is on the temporary expropriation of inner-city buildings for housing purposes (including low-income housing and alternative accommodation). She acknowledges 
primary reason for the court's not ordering one of these instead of compensation. ${ }^{101}$ Accordingly, both alternative accommodation orders and compensation orders amount to the court's requiring the state's fulfilment of its housing duty.

Since a compensation order amounts to a requirement on the state to fulfil its housing duty as formulated in section 26(2) of the Constitution, the internal limitations of section 26(2) apply. The court may grant a compensation order that is within the state's available resources. ${ }^{102}$ However, if the role of the compensation order in fulfilling the state's housing duty is not acknowledged, the internal limitations of the state's short-term housing duty will effectively be bypassed. ${ }^{103}$ This is nonsensical, considering that one of the reasons for awarding damages instead of ordering expropriation, for example, is to limit interference with the state's functions. Yet the effect of the damages award could be a greater interference than is constitutionally permitted.

This article submits that, since the compensation order effectively amounts to the state's fulfilling its housing duty, the court should take into account the state's available resources when awarding constitutional damages. ${ }^{104}$ In fact, in Modderklip the court did seem to take cognisance of the state's limited resources. The court considered the state to have sufficient resources to expropriate the property. ${ }^{105}$ This is consistent with a general unwillingness by the courts to accept the state's argument that it does not have the available resources to provide even basic shelter to unlawful occupiers. ${ }^{106}$ Unfortunately, in Modderklip the court did not base its finding

that this tool can be used also in matters like $P E$ Municipality, to temporarily expropriate the unlawfully occupied private land.

101 See Modderklip para 62, where the court so avers. Also see Fischer v Persons Listed on Annexure $X$ to the Notice of Motion and those Persons whose Identity are Unknown to the Applicant and who are Unlawfully Occupying or Attempting to Occupy Erf 150 (Remaining Extent) Phillipi, Cape Division, Province of the Western Cape; Stock v Persons Unlawfully Occupying Erven 145, 152, 156, 418, 3107, Phillipi \& Portion 0 Farm 597, Cape Rd; Copper Moon Trading 203 (Pty) Ltd v Persons whose Identities are to the Applicant Unknown and who are Unlawfully Occupy Remainder Erf 149, Phillipi, Cape Town 20182 SA 228 (WCC) para 167, where the court orders the consideration of purchase and expropriation without ordering these steps directly to avoid a violation of the separation of powers doctrine.

102 Section 26(2) of the Constitution.

103 This is alluded to in Viljoen 2015 SAPL 46, who writes that in Modderklip the court bypassed the eviction and allocation of land issue.

104 Kotzé agrees to some extent in Kotzé Effective Relief Regarding Residential Property 120, 121.

105 Modderklip para 50.

106 See for example Blue Moonlight para 73, where the court was satisfied that the municipality had funding due to an overall projected budget surplus. For an argument that this approach of the court is justified, see Liebenberg 2005 SAJHR 21-30. 
that the state had the resources to expropriate the land on fact; nor did it try to determine whether the state had the resources to comply with its order. ${ }^{107}$

It should be stressed that the conclusion that the court must take into account the available resources of the state does not mean that the state should be able to simply argue that it does not have the available resources. The courts should be commended for not easily accepting an argument regarding the unavailability of resources. It should be very difficult for the state to succeed in an argument that it does not have sufficient resources. This is because the state carries the burden of proof regarding its available resources in eviction matters. ${ }^{108}$ Moreover, all spheres of government are responsible for providing emergency housing and the enquiry into whether the state has the available resources should not be limited to the resources of the relevant municipality. ${ }^{109}$

Thus, an award of constitutional damages in delayed eviction matters amounts to the state providing the unlawful occupiers with housing and should take cognisance of the state's available resources. What needs to be addressed, though, is the relevance of this finding to determining whether such relief is appropriate, just and equitable. The following section aims to provide an answer to this question.

\section{Constitutional damages as relief}

As already explained, the Constitution requires that relief for the violation of a fundamental right should be appropriate, just and equitable. A distinction between the concepts "appropriate" and "just and equitable" may seem superficial. That is because a remedy that is not just and equitable would not be appropriate and vice versa. A basic distinction between the two concepts is that "appropriateness" has more to do with the interests of the victim(s) and justice and equity more to do with balancing these interests against the interests of others that may be affected. The distinction is not always clear cut, since the interests of others may play a role in the determination of "appropriateness".

107 As explained in PE Municpality para 32: "In securing the necessary information, the court would therefore be entitled to go beyond the facts established in the papers before it. Indeed when the evidence submitted by the parties leaves important questions of fact obscure, contested or uncertain, the court might be obliged to procure ways of establishing the true state of affairs, so as to enable it properly to 'have regard' to relevant circumstances."

108 Changing Tides paras 28-38, referring to PE Municipality para 32.

109 All spheres of government must commit to housing: Grootboom para 39; Viljoen 2015 SAPL 51. Also see 2.6.2, 2.6.3, 3.2 of the EHP (DHS National Housing Code Part 3). These parts require collaboration between the spheres of government and enabling municipalities to apply for funding from the other spheres of government. 
To keep the distinction simple, this article focuses on whether the remedy should be granted under the "appropriateness" heading (focussing mainly on the interests of the victim(s)) and how the remedy should be granted under the "just and equitable" heading (focussing on balancing the interests of the victim(s) with those of other affected parties). In other words, it asks whether granting the remedy of constitutional damages would be appropriate and, if so, how it should be granted to ensure that it is just and equitable.

While the focus of the article is on the award of constitutional damages as relief in delayed eviction matters, it acknowledges that another suggested form of relief would be the amendment of PIE to make provision for the award of compensation in such matters. ${ }^{110}$ This would be more in line with the single-system-of-law principle. ${ }^{111}$ This remedy is not dealt with separately in this article. This is simply because a decision to add such a provision and the application thereof would still have to comply with the constitutional requirements of appropriateness, justness and equitableness if it is aimed at remedying violations of fundamental rights. ${ }^{112}$ Accordingly, the arguments in this article would similarly apply.

A further point to note is that, given the conclusions reached in the previous section, this section is not exclusively focussed on whether the relief would be appropriate, just and equitable for the violation of the landowner's property right. It also considers the fact that the relief is simultaneously aimed at remedying the state's violation of the unlawful occupiers' housing right. In a delayed eviction matter, the delay occurs because the state failed to fulfil its housing duty toward the unlawful occupiers. This amounts to a violation of their rights, provided that the state had the available resources to fulfil its duty (taking into account that such an argument would rarely

110 See Bezuidenhout Compensation for Excessive but Otherwise Lawful Regulatory State Action 283; Kruger 2014 SALJ 361; Kotzé Effective Relief Regarding Residential Property 187-190; Van der Walt Constitutional Property Law 280-281. PIE does, in fact, make provision for a court to attach conditions to an eviction order (s 4(12)).

111 This notion suggests that all law is part of one system and that there are rules regarding which laws to apply to a dispute based on the hierarchy of the sources of law. The Constitution tops the hierarchy and all laws must comply with it. This means that legislation giving effect to constitutional rights must comply with the Constitution. This relates to the principle of subsidiarity that requires persons to rely on legislation giving effect to constitutional rights instead of relying directly on these rights. Hence, when such legislation does not provide the full range of remedies allowed by the right, it should be amended. See Van der Walt Property and Constitution 19-26, 36.

112 Since it would give effect to ss 38 and 172 of the Constitution. The same is argued in respect of the compensation remedy available in terms of the Promotion of Administrative Justice Act 3 of 2000 for violations of the right to administrative justice. See De Ville Judicial Review of Administrative Action 353-354. 
succeed). ${ }^{113}$ Hence, a remedy should amount to appropriate, just and equitable relief for both the landowner and the unlawful occupiers.

\subsection{Constitutional damages as appropriate relief}

In MEC for the Department of Welfare $v$ Kate (hereafter Kate), ${ }^{114}$ the SCA found that, in considering the appropriateness of the relief granted for the violation of a constitutional right, regard must be had to factors such as: ${ }^{115}$

the nature and relative importance of the rights that are in issue, the alternative remedies that might be available to assert and vindicate them, and the consequences of the breach for the claimant concerned.

In applying these factors, the "consequences of the breach" of the landowner's property right concern not only that the landowner's interests but also the unlawful occupiers' housing right. Therefore, appropriate relief must be aimed at giving effect to both of these rights.

When considering the "nature" of these rights, they include requirements, duties and limitations. Appropriate relief would be sensitive to the requirements, duties and limitations of both of these rights. An award of constitutional damages does not take these into account. It ignores the duties that the landowner continues to carry during the delay. This includes the payment of rates and taxes. Also, it does not take cognisance of the requirements included in the realisation of the right to access to adequate housing, such as the provision of basic services. ${ }^{116}$ It also does not consider the limitations internal to the right to access to adequate housing, including that the state needs to fulfil it only within its available resources.

Another form of relief that takes this into account may be more appropriate. This relates to the third factor mentioned above: "alternative remedies that might be available". Three alternative remedies are discussed below: an eviction order, delictual damages, and a structural interdict. Even if one of these remedies is available, this does not mean that constitutional damages would not be appropriate, since the availability of alternative remedies is not decisive but is only one factor to consider. ${ }^{117}$

The author acknowledges that other remedies may also be available, such as the court's ordering the state to expropriate or purchase the property. These remedies are not discussed here since they remain controversial due to concerns about the separation of powers. The Supreme Court of Appeal recently ordered the City of Cape Town to purchase unlawfully occupied

See the discussion in section 4 above.

MEC for the Department of Welfare $v$ Kate 20064 SA 478 (SCA) (hereafter Kate).

Kate para 25. See also, Kotzé Effective Relief Regarding Residential Property 129.

As interpreted in Grootboom para 35, referred to in Viljoen 2015 SAPL 47.

Kate para 27. 
land, albeit by agreement, ${ }^{118}$ but discussion of this case is beyond the scope of this article.

\subsubsection{Availability of an eviction order}

The most appropriate form of relief for the landowner, in eviction matters, would be aimed at preventing the (further) violation of the landowner's rights. Such relief would be an eviction within a reasonable period. However, the unlawful occupiers' rights are also affected. Even if the state does not have sufficient resources to accommodate them elsewhere within a reasonable period, it may have enough resources to provide the landowner with just and equitable compensation for the use of its property to house the occupiers. To allow for such compensation, an award of constitutional damages may be appropriate (in addition to or alternative to an eviction order).

\subsubsection{Availability of delictual damages}

In Modderklip the court found that the landowner could have claimed delictual damages. The court did not require the landowner to do so under the circumstances, due to the long delay a separate application would have caused. ${ }^{119}$ The question is whether delictual damages would be more appropriate in other delayed eviction matters.

Since the relief granted must also be appropriate for unlawful occupiers, an award of delictual damages would not be appropriate relief. That is because delictual damages is a private law remedy. ${ }^{120}$ It is backwards-looking. ${ }^{121}$ This means that it is aimed only at compensating the victim for his loss. ${ }^{122}$ It does not take into account the interests of others affected. ${ }^{123}$ Full compensation is required. ${ }^{124}$ The award of constitutional damages is a public law remedy. It is forward-looking and considers the interests of others. ${ }^{125}$ Full compensation is not required. Instead, courts are granted the discretion to make an order that is just and equitable, taking into account

118 Coppermoon Trading 203 (Pty) Ltd $v$ The Persons whose Identities are to the Applicant Unknown and Unlawfully Occupy Remainder Erf 148, Phillipi, Cape Town (SCA) (unreported) case number 653/18, 701/18, 821/18, 708/18 of 4 March 2020.

119 Modderklip para 59.

120 Price 2015 Acta Juridica 320.

121 Price 2015 Acta Juridica 320. Also see Mbazira Litigating Socio-economic Rights 14, $104,106,107$. He explains that private law remedies such as delictual damages are linked with corrective justice, which simply aims at putting the victim in the position he was in before the damage ocurred.

122 Price 2015 Acta Juridica 320. Also see Mbazira Litigating Socio-economic Rights 14, 104.

123 Price 2015 Acta Juridica 320. Also see Mbazira Litigating Socio-economic Rights 106.

124 Price 2015 Acta Juridica 326.

125 Price 2015 Acta Juridica 320. Also see Mbazira Litigating Socio-Economic Rights 14, 162. Mbazira explains that the constitutional remedies are forward-looking due to the notion of distributive justice. 
the interests of others. ${ }^{126}$ Thus, an award of constitutional damages would be more appropriate because it would allow the court to take into account the interests of the unlawful occupiers, as well as others who may be affected, when determining the amount of damages.

\subsubsection{Availability of a structural interdict}

A structural interdict is supervisory in nature. The court retains jurisdiction over the matter to ensure compliance with its orders. In practice this entails a declaration by the court that the state's conduct was unconstitutional. Also, the court orders the state to report on how it plans to remedy the unconstitutionality. The report is then made a court order. ${ }^{127}$ Structural interdicts allow the state to decide how to perform its duties while adhering to the principle of the separation of powers. ${ }^{128}$ Its granting is appropriate in matters where there is evidence that the state may be unwilling to comply with an order requiring it to fulfil its constitutional duties. ${ }^{129}$

In delayed eviction matters, a structural interdict would involve a declaration by the court that a delay has violated or would violate the rights of the landowner and the unlawful occupiers. An eviction order without alternative accommodation would violate the rights of the unlawful occupiers. It would then order the state to submit a report on how it plans to give effect to these rights. This could include the provision of alternative land, as well as the renting, purchase or (temporary) expropriation of the currently occupied land.

Viljoen argues that the remedy of constitutional damages as a sole remedy is inappropriate because, amongst other things, it does not require the state to provide the occupiers with basic services. ${ }^{130}$ This conflicts with the state's housing duty, which includes the provision of basic services. ${ }^{131}$ Moreover, simply requiring the state to pay constitutional damages has the effect that the occupiers remain where they are unlawfully. This negatively affects their tenure security. Viljoen argues that the court in Modderklip should have made it clear that the continued occupation would be lawful. ${ }^{132}$ The occupiers should have been provided with a degree of tenure security.

The above arguments link with the fact that an award of constitutional damages amounts to the fulfilment of the state's housing duty. However, it highlights the fact that an award of constitutional damages does not sufficiently realise the unlawful occupiers' rights. In ignoring the fact that the

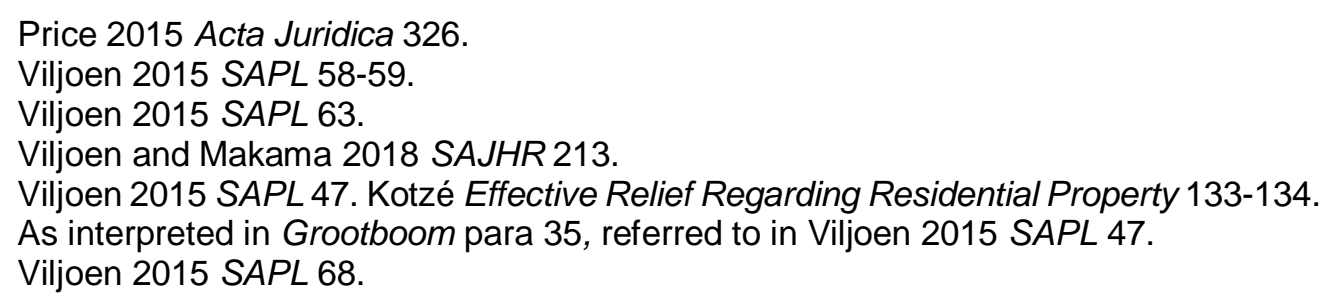


order is two-pronged (it gives effect not only to the landowner's rights but also to those of the unlawful occupiers), the court fails to give effect to the duties and limitations on the state in realising the unlawful occupiers' rights.

A structural interdict best takes into account the fact that the relief to be ordered is aimed not only at giving effect to the landowner's rights but also to those of the unlawful occupiers. That is because it allows the state to present a plan that best fulfils its duties toward both the landowner and the unlawful occupiers. This solution would be sensitive to the state's available resources, as is required of relief aimed at giving effect to the unlawful occupiers' housing rights.

Certain options available to the state, such as purchasing or expropriating the land, would also solve the problems created for the landowner by an award of constitutional damages. One such problem is that the landowner remains the owner of the property. ${ }^{133}$ As the owner, the landowner would retain certain duties toward the land, such as the duty to pay municipal rates and taxes. While an order to expropriate the property could solve this, courts seem reluctant to make such orders due to the principle of the separation of powers. ${ }^{134}$ Accordingly, it may be more appropriate to leave the decision on how to give effect to the landowner's rights to the state.

While a structural interdict may seem to be the most appropriate remedy, there may be situations where an award of constitutional damages is appropriate in addition to structural interdicts. This would be the case if the landowner would still suffer an unreasonable delay in regaining possession of its property. That is, if the plan submitted to the court and the execution thereof takes unreasonably long (resulting in the arbitrary deprivation of property). ${ }^{135}$ Moreover, while it seems unlikely, there might still be circumstances in which a court concludes that an award of constitutional damages would be an (or the most) appropriate remedy.

From this section, it is evident that an award of constitutional damages is probably not the most appropriate relief in delayed eviction matters. Instead, a structural interdict would be the most appropriate remedy. In limited instances, an order of constitutional damages may be appropriate in addition to a structural interdict. There might also be circumstances in which a court concludes that an award of constitutional damages would be an (or

133 This would have given owner more certainty, Kotzé Effective Relief Regarding Residential Property 134, referring to Strydom and Viljoen 2014 PELJ 1234.

134 This is evident from the court's rejection of an order that the state purchase property based on concerns about the separation of powers, in Ekurhuleni Metropolitan Municipality v Dada 20094 SA 463 (SCA). Kotzé argues, with reference to this case, that the court does not have the power to expropriate in Kotzé Effective Relief Regarding Residential Property 131. Also see Dugard 2018 PELJ 1-20.

135 However, even in such situations the state could include compensation for the landowner in its plan for the vindication of the rights. 
the most) appropriate remedy. If a court is to consider an award of constitutional damages an appropriate remedy (either as a complementary or a primary remedy), it must also find that such a remedy would be just and equitable. The following section considers how constitutional damages should be granted to ensure that the grant is just and equitable.

\subsection{Constitutional damages as just and equitable relief}

Relief granted in terms of section 38 of the Constitution must be just and equitable. ${ }^{136}$ As already explained, this criterion requires that the interests of all persons affected by the order be balanced. ${ }^{137}$ Hence, the order should not be just and equitable toward the landowner only, but also toward all persons affected by the order. ${ }^{138}$ Since the award of constitutional damages in a delayed eviction is a means of realising the state's short-term housing duty, the persons affected by the order include the unlawful occupiers before the court. However, it also includes those in similar positions as the landowner and the unlawful occupiers in the matter before the court; in other words, those landowners who will still approach the court for an eviction order and those unlawful occupiers who will still face eviction. These people are affected by the court's order because the order will affect the state's available resources. The higher the compensation amount is, the lower the remaining resources are. Lower remaining resources mean that the state will have fewer funds with which to provide alternative accommodation to those facing eviction in the same budgetary cycle, as well as less money to compensate other landowners experiencing an unreasonable delay in an eviction matter.

To take into account all of these interests, a just and equitable order by the court would have to adhere to the principle of distributive justice. Distributive justice requires that resources be distributed fairly amongst the members of a specified group. ${ }^{139} \mathrm{~A}$ decision to distribute resources cannot be made without considering the interests of all of the members of the group. ${ }^{140}$

\subsubsection{The application of distributive justice}

Adherence to the principle of distributive justice requires that consideration be taken of the state's short-term housing budget, ${ }^{141}$ as well as the

136 Section 172(1)(b) of the Constitution.

137 PE Municipality paras 33,37 . That the interests of the public must weigh in the balance is confirmed in Residents of Joe Slovo Community, Western Cape $v$ Thubelisha Homes 20103 SA 454 (CC) paras 99, 101. Also see Pope 2011 Speculum Juris 136137, 143; Chenwi 2008 HR L Rev 134; Mostert "Landlessness, Housing and the Rule of Law" 93; Bishop "Remedies" 9-56.

138 Absa Bank Bpk v Murray 2003 ZAWCHC 48 (18 September 2003) para 22.

139 Cook and Hegtvedt 1983 Annu Rev Sociol 218.

140 Mbazira Litigating Socio-economic Rights 113, 139.

141 The state's entire housing budget should not be considered because the Constitutional Court, in Grootboom, specifically states that a government should have short-, 
possibility of other emergency housing situations in the same budgetary cycle, that would require resources. ${ }^{142}$ If this does not occur, one party may be advantaged based solely on how early in the year its matter appears before the court. Ideally, there should be sufficient funds to provide accommodation to all persons facing housing emergencies, and the funds should be distributed equally.

To assist all persons in housing emergencies and ensure that no-one becomes homeless, the standard of the housing provided may need to be lower. The problem comes in when there are not enough resources to provide even the most basic emergency accommodation to those in need. One would have to determine which persons to prioritise. Currently, the effect of the court's disregard of the distributive effects of its orders is that prioritisation is determined solely on a first come first served basis. This article submits that prioritisation should rather be based on need. ${ }^{143}$

Rawls supports "need" as a principle for prioritisation in distribution matters, arguing that a distribution may be just if it is "to the greatest benefit of the least advantaged". ${ }^{144}$ One application of "need" as a principle of distribution is to prioritise those that are the "poorest of the poor" or are part of an especially vulnerable group. ${ }^{145}$ In terms of PIE, this includes woman-headed households, children, disabled persons and elderly persons. ${ }^{146}$ Prioritisation based on need in this way requires that the court knows the specific circumstances of each individual requiring housing. This could be impossible in large-scale unlawful occupation. Moreover, it would lead to superficial prioritisation, suggesting that the homelessness of some is more acceptable than that of others. This is inconsistent with the notion of inherent human dignity. ${ }^{147}$ "Need" in the sense of extreme poverty or vulnerability should rather play a role in the initial determination regarding whether a person can secure alternative accommodation for themselves.

Another possible application of "need" as a principle of distribution is to consider the urgency of the existing and potential upcoming emergency housing situations within the municipality's jurisdiction in the current

medium- and long-term programmes. One programme should not be prioritised above the others. See Grootboom para 43.

142 This is not limited to eviction proceedings but includes all housing emergencies, such as when a person's house was burned down or was destroyed during a flood.

143 See Deutsch 1975 J Soc Issues 137-149; Wagstaff 1994 Curr Psychol 138; Cook and Hegtvedt 1983 Annu Rev Sociol 217-241.

144 This is part of Rawl's second principle in Rawls Theory of Justice 266.

145 Grobler v Msimanga 20083 All SA 549 (W) para 116. Also see Grootboom para 44.

146 Sections 4(6) and 4(7) of PIE. Also see Muller 2014 SAJHR 46; Sen 1990 Philos Public Aff 114, 116.

147 On the importance of shelter in recognising dignity, see Grootboom para 23. An exception might be that the person is to blame for his/her homelessness. Such persons are excluded from benefitting in terms of the EHP. 
budgetary cycle. Compare: (1) a group of persons left homeless after their homes have burned down, (2) a group of persons unlawfully occupying another's home, and (3) a group of persons unlawfully occupying land earmarked for private commercial development. The needs of those whose homes have burned down may be the greatest, since the emergency housing situation cannot be postponed. The urgency of the eviction of the group occupying another's home is greater than that of the group occupying the land to be developed. This is especially true in matters where the developer knew that the land was unlawfully occupied when purchasing it.

Moreover, and that is the point of this section, a court can "make" the emergency housing situations in the matters of unlawful occupation less urgent by ordering the state to compensate the landowner and delaying the eviction. ${ }^{148}$ This directly affects the short-term housing duties of the state and the moneys required should be paid out of its short-term housing budget. ${ }^{149}$ Thus, the state's available resources should be considered when determining the amount of compensation. Moreover, distributive justice requires that the effect of the compensation order on the state's ability to address more urgent emergency housing situations in its jurisdiction must be considered.

\subsubsection{Arguments against the application of distributive justice}

There are three possible counterarguments to applying distributive justice when determining the amount of constitutional damages in delayed eviction matters. The first is that the state's available resources should not be relevant because the argument that the compensation amounts to the fulfilment of its housing duty is incorrect. The second is that the principle of corrective justice is a more appropriate form of justice to apply. The third is that the state's available resources need not be considered because the relief is to act as a deterrent.

5.2.2.1 The payment of constitutional damages is not a fulfilment of the state's housing duty

Arguably, compensation orders do not reduce the resources available in the state's existing short-term housing budget. If compensation orders are not considered as part of the fulfilment of the state's housing duty, the compensation would not be paid from the short-term housing budget.

148 Kotzé refers to this effect of a compensation order in Kotzé Effective Relief Regarding Residential Property 127.

149 Grootboom paras 66-68 requires that a part of the national housing budget be devoted to emergency housing needs. This was confirmed in Blue Moonlight paras 57, 63, 6667 , in which the court found that municipalities could be required to self-fund emergency housing and that they have a duty to plan and budget for emergency housing situations. This corresponds with 3.2.1 of the EHP (DHS National Housing Code Part 3). 
However, if compensation orders are granted, the state would have to budget for this kind of order, depleting the money budgeted for other things, like housing. Such orders may also be paid out of the state's surplus money, money that could be used (and has been used in the past) ${ }^{150}$ to fulfil the state's short-term housing duty. Hence, even if a compensation order is not considered a fulfilment of the state's short-term housing duty, distributive justice still requires that the court considers the state's available resources and the needs of potential subsequent emergency housing situations during the current budgetary cycle when determining the compensation amount.

\subsubsection{The principle of corrective justice should apply}

Another counterargument to applying distributive justice in determining compensation is that corrective justice should rather be applied in delayed eviction matters. Corrective justice is relevant when someone is harmed by another. It requires that the person who caused another person harm repair it. ${ }^{151}$ Thus, the victim's loss is fully remedied. The remedy is not influenced by the interests of others affected by the order.

In respect of delayed evictions, the state caused the landowner harm. This is because it is the state that needs to authorise the eviction through PIE. Nevertheless, corrective justice as the sole form of justice would not be desirable in delayed eviction matters. That is because it ignores the reality of the compensation order, which is to provide housing to the unlawful occupiers. Moreover, since it does not consider the distributive effect of the remedy, it may prevent future claims by landowners for corrective justice due to a depletion of the state's resources. ${ }^{152}$ Therefore, corrective justice should apply to the extent that it requires the municipality to repair the harm caused. However, distributive justice should apply concurrently, possibly reducing the extent of the correction based on the state's available resources. This is in line with the interpretation that the "just and equitable" requirement for relief ordered by the court necessitates consideration of the needs of others affected by the order.

\subsubsection{Constitutional damages as a deterrent}

A further argument against considering the state's ability to address future emergency housing situations when determining the compensation amount is that the compensation order should act as a deterrent to the state from

\footnotetext{
150 In Blue Moonlight the state was required to pay for the provision of alternative accommodation out of its surplus.

151 Weinrib 2002 UTLJ 349; Mbazira Litigating Socio-economic Rights 9, 163; Aristotle Nicomachean Ethics 77-84. Also see Modak-Truran 2000 Yale J L \& Human 252, 256; Roach 1991 Arizona L Rev 860-871; Klimchuk 2003 OJLS 56; Posner 1981 JLS 190, 195-196, 200; Coleman 1982 JLS 436.

152 Weinrib 2002 UTLJ 351-352.
} 
neglecting its duties in the future. ${ }^{153}$ If successful, no future emergency housing situations would be brought to court. Accordingly, the effect of the order on future constitutional damages awards need not be considered.

Distributive justice allows for compensation as a deterrent. ${ }^{154}$ Nevertheless, in Fose the Constitutional Court rejected the notion that constitutional damages should be awarded as a deterrent on the basis that there is no real proof of success. ${ }^{155}$ Ordering the state to use its limited resources in this way is counterproductive in matters pertaining to socio-economic rights. ${ }^{156}$ Rather than encouraging the state to fulfil its duties toward others in similar positions, it limits its ability to do so. ${ }^{157}$ This prejudices those in a similar position. ${ }^{158}$ Moreover, taxpayers' money is used to deter. It is not the state being punished but the public, on all accounts. ${ }^{159}$ Also, compensation as a deterrent can succeed only if the housing emergency is due to the state neglecting its duties (and the state must be deterred from similarly neglecting its duties in the future). If the state acted reasonably and was still unable to solve the unlawful occupiers' emergency housing dilemma, compensation as a deterrent would not be appropriate.

\subsubsection{The practicalities of applying distributive justice}

It must be determined how considering the state's available resources and the needs of others would work in practice. It is extremely difficult for the court to know all of the other possible emergency housing situations within its jurisdiction. Moreover, it must be stressed that this requirement should not be used as an excuse by the state for not fulfilling its duties.

Some suggestions to simplify the court's task can be made. First, the court must, at the very least, take cognisance of the fact that there might be other unlawful occupations within the municipality's jurisdiction in the same budgetary cycle when deciding on an amount of compensation. The amount should not deplete the state's proven available resources. Importantly, the court should not limit its consideration of the available resources to the municipality's budget but should also consider the ability of the provincial and national spheres of government to assist. ${ }^{160}$ A second way of simplifying the court's task is for it to require the state to persuade it of its

\footnotetext{
153 Mbazira Litigating Socio-economic Rights 144-145.

154 Mbazira Litigating Socio-economic Rights 144-145.

155 Fose para 71. Also see Mbazira Litigating Socio-economic Rights 150.

156 Fose para 72. Also see Mbazira Litigating Socio-economic Rights 150, 153.

157 Mbazira Litigating Socio-economic Rights 164.

158 Mbazira Litigating Socio-economic Rights 150.

159 Kotzé Effective Relief Regarding Residential Property 134.

160 All spheres of government must commit to housing: Grootboom para 39; Viljoen 2015 $S A P L 51$. Since this consideration may be difficult for the court without the necessary information before it, the second way of simplifying the court's task can be used.
} 
unavailable resources. ${ }^{161} \mathrm{~A}$ third practical manner of applying the principle of distributive justice is to determine compensation based on section 25(3) of the Constitution, the section dealing with determining just and equitable compensation in expropriation matters. ${ }^{162}$ Doing so would allow the court to take into account several factors to reduce the compensation amount and the burden on the state's resources. ${ }^{163}$

\section{Conclusion}

The purpose of this article was to determine whether an award of constitutional damages in delayed eviction matters would be appropriate, just and equitable. The main argument made in the article is that an award of constitutional damages amounts to the fulfilment of the state's short-term housing duty toward the unlawful occupiers. This means that the requirements and limitations of this duty must be taken into account when determining whether relief would be appropriate, just and equitable. Usually, the most appropriate relief in delayed eviction matters would be a structural interdict. This relief best takes into account the fact that the vindication of the landowner's housing right is also involved. Sometimes an award of constitutional damages in addition to a structural interdict would be appropriate, such as when the landowner would still suffer an unreasonable delay in regaining possession of its property. Moreover, there might still be circumstances in which a court concludes that an award of constitutional damages would be an (or the most) appropriate remedy.

If, however, a court finds that an award of constitutional damages (as a complementary or the primary remedy) would be an appropriate remedy, the principle of distributive justice must be applied in determining the amount to be paid. This would ensure that the relief is just and equitable. Distributive justice requires that the court not only consider the state's ability, based on its resources, to give effect to the rights in the matter before the court, but also how the court's order will affect the state's ability to give effect to the rights of those similarly situated.

161 See Chenwi 2008 HR L Rev 123-124 fn 79. Chenwi refers to cases in which the court has done this: Minister of Health v Treatment Action Campaign 20025 SA 721 (CC); Khosa $v$ Minister of Social Development 20046 SA 505 (CC).

162 This is suggested in Kruger 2014 SALJ 363; Kotzé Effective Relief Regarding Residential Property 189-190.

163 Due to constraints of space, examples of how this would work cannot be provided here. 


\section{Bibliography}

\section{Literature}

Aristotle Nicomachean Ethics

Aristotle Nicomachean Ethics Ross WD (Translator) (Batoche Books Kitchener 1999)

Bezuidenhout Compensation for Excessive but Otherwise Lawful Regulatory State Action

Bezuidenhout $\mathrm{K}$ Compensation for Excessive but Otherwise Lawful Regulatory State Action (LLM-dissertation University of Stellenbosch 2015)

Bishop "Remedies"

Bishop M "Remedies" in Woolman S and Bishop M (eds) Constitutional Law of South Africa $2^{\text {nd }}$ ed (Juta Cape Town 2013) ch 9

Calabresi and Melamed 1972 Harv L Rev

Calabresi $G$ and Melamed AD "Property Rules, Liability Rules, and Inalienability: One View of the Cathedral" 1972 Harv L Rev 1089-1128

Chenwi 2008 HR L Rev

Chenwi L "Putting Flesh on the Skeleton: South African Judicial Enforcement of the Right to Adequate Housing of those Subject to Evictions" 2008 HR L Rev 105-137

Chenwi 2009 CCR

Chenwi L "A New Approach to Remedies in Socio-economic Rights Adjudication: Occupiers of 51 Olivia Road v City of Johannesburg" 2009 CCR 371-393

Coleman 1982 JLS

Coleman J "Corrective Justice and Wrongful Gain" 1982 JLS 421-440

Cook and Hegtvedt 1983 Annu Rev Sociol

Cook KS and Hegtvedt KA "Distributive Justice, Equity, and Equality" 1983 Annu Rev Sociol 217-241

De Ville Judicial Review of Administrative Action

De Ville JR Judicial Review of Administrative Action in South Africa (LexisNexis Durban 2003)

Deutsch 1975 J Soc Issues

Deutsch M "Equity, Equality, and Need: What Determines which Value will be Used as the Basis of Distributive Justice?" 1975 J Soc Issues 137-149

DHS National Housing Code Part 3 
Department of Human Settlements The National Housing Code: Incremental interventions - Part 3: Emergency Housing Programme (Department of Human Settlements Pretoria 2009)

Dugard 2018 PELJ

Dugard J "Modderklip Revisited: Can Courts Compel the State to Expropriate Property Where the Eviction of Unlawful Occupiers is not Just and Equitable?" 2018 PELJ 1-20

Klimchuk 2003 OJLS

Klimchuk D "On the Autonomy of Corrective Justice" 2003 OJLS 49-64

Kotzé Effective Relief Regarding Residential Property

Kotzé T Effective Relief Regarding Residential Property Following a Failure to Execute an Eviction Order (LLM-dissertation University of Stellenbosch 2016)

Kruger 2014 SALJ

Kruger M "Arbitrary Deprivation of Property: An Argument for the Payment of Compensation by the State in Certain Cases of Unlawful Occupation" 2014 SALJ 328-364

Liebenberg 2005 SAJHR

Liebenberg $S$ "The Value of Human Dignity in Interpreting Socioeconomic Rights" 2005 SAJHR 1-30

Mbazira Litigating Socio-economic Rights

Mbazira C Litigating Socio-economic Rights in South Africa - A Choice between Corrective and Distributive Justice (Pretoria University Law Press Pretoria 2009)

Modak-Truran 2000 Yale J L \& Human

Modak-Truran MC "Corrective Justice and the Revival of Judicial Virtue" 2000 Yale J L \& Hum 249-298

Mostert "Landlessness, Housing and the Rule of Law"

Mostert $\mathrm{H}$ "Landlessness, Housing and the Rule of Law" in Mostert $\mathrm{H}$ and De Waal MJ (eds) Essays in Honour of CG van der Merwe (LexisNexis Durban 2011) 73-104

Muller 2011 Stell LR

Muller G "Conceptualising "Meaningful Engagement" as a Deliberative Democratic Partnership" 2011 Stell LR 742-758

Muller 2014 SAJHR

Muller G "On Considering Alternative Accommodation and the Rights and Needs of Vulnerable People" 2014 SAJHR 41-62

Muller and Liebenberg 2013 SAJHR 
Muller $\mathrm{G}$ and Liebenberg $S$ "Developing the Law of Joinder in the Context of Evictions of People from their Homes" 2013 SAJHR 554-570

Pienaar Land Reform

Pienaar JM Land Reform (Juta Cape Town 2014)

Pope 2011 Speculum Juris

Pope A "The Alternative Accommodation Conundrum: Trends and Patterns in Eviction Jurisprudence" 2011 Speculum Juris 134-147

Posner 1981 JLS

Posner RA "The Concept of Corrective Justice in Recent Theories of Tort Law" 1981 JLS 187-206

Price 2015 Acta Juridica

Price A "State Liability and Accountability" 2015 Acta Juridica 313-335

Rawls Theory of Justice

Rawls J A Theory of Justice (Belknap Press of Harvard University Press Cambridge 1999)

Roach 1991 Arizona L Rev

Roach $\mathrm{K}$ "The Limits of Corrective Justice and the Potential of Equity in Constitutional Remedies" 1991 Arizona L Rev 859-905

Roach and Budlender 2005 SALJ

Roach $\mathrm{K}$ and Budlender $\mathrm{G}$ "Mandatory Relief and Supervisory Jurisdiction: When is it Appropriate, Just and Equitable?" 2005 SALJ 325-351

Sen 1990 Philos Public Aff

Sen A "Justice: Means versus Freedoms" 1990 Philos Public Aff 111-121

Strydom and Viljoen 2014 PELJ

Strydom J and Viljoen S "Unlawful Occupation of Inner-city Buildings: A Constitutional Analysis of the Rights and Obligations Involved" 2014 PELJ 1207-1261

Tushnet 2003 ICON

Tushnet $\mathrm{M}$ "The Issue of State Action/Horizontal Effect in Comparative Constitutional Law" 2003 ICON 79-98

Van der Walt Constitutional Property Law

Van der Walt AJ Constitutional Property Law $3^{\text {rd }}$ ed (Juta Cape Town 2011)

Van der Walt Property and Constitution

Van der Walt AJ Property and Constitution (Pretoria University Law Press Pretoria 2012)

Van der Walt 2005 SAJHR 
Van der Walt AJ "The State's Duty to Protect Property Owners v the State's Duty to Provide Housing: Thoughts on the Modderklip Case" 2005 SAJHR 144-161

Viljoen 2014 TSAR (Part 1)

Viljoen $S$ "The Temporary Expropriation of a Use Right as Interim Measure in the South African Housing Context (Part 1)" 2014 TSAR 359-376

Viljoen 2014 TSAR (Part 2)

Viljoen $S$ "The Temporary Expropriation of a Use Right as Interim Measure in the South African Housing Context (Part 2)" 2014 TSAR 520-535

Viljoen 2015 SAPL

Viljoen S "The Systemic Violation of Section 26(1): An Appeal for Structural Relief by the Judiciary" 2015 SAPL 42-70

Viljoen and Makama 2018 SAJHR

Viljoen S and Makama SP "Structural Relief - A Context-sensitive Approach" 2018 SAJHR 209-230

Wagstaff 1994 Curr Psychol

Wagstaff GF "Equity, Equality, and Need: Three Principles of Justice or One? An Analysis of 'Equity as Desert"' 1994 Curr Psychol 138-152

Weinrib 2002 UTLJ

Weinrib EJ "Corrective Justice in a Nutshell" 2002 UTLJ 349-356

Wilson 2009 SALJ

Wilson S "Breaking the Tie: Evictions from Private Land, Homelessness and a New Normality" 2009 SALJ 270-290

Wilson 2011 Urban Forum

Wilson S "Planning for Inclusion in South Africa: The State's Duty to Prevent Homelessness and the Potential of 'Meaningful Engagement'" 2011 Urban Forum 265-282

\section{Case law}

Absa Bank Bpk v Murray 2003 ZAWCHC 48 (18 September 2003)

Arendse $v$ Arendse 20133 SA 347 (WCC)

City of Johannesburg v Changing Tides 74 (Pty) Ltd 20126 SA 294 (SCA) City of Johannesburg Metropolitan Municipality v Blue Moonlight Properties 39 (Pty) Ltd 20122 SA 104 (CC)

City of Johannesburg Metropolitan Municipality v Hlophe 20152 All SA 251 (SCA) 
Coppermoon Trading 203 (Pty) Ltd $v$ The Persons whose Identities are to the Applicant Unknown and Unlawfully Occupy Remainder Erf 148, Phillipi, Cape Town (SCA) (unreported) case number 653/18, 701/18, 821/18, $708 / 18$ of 4 March 2020

\section{Ekurhuleni Metropolitan Municipality v Dada 20094 SA 463 (SCA)}

Fischer $v$ Persons Listed on Annexure $X$ to the Notice of Motion and those Persons whose Identity are Unknown to the Applicant and who are Unlawfully Occupying or Attempting to Occupy Erf 150 (Remaining Extent) Phillipi, Cape Division, Province of the Western Cape; Stock v Persons Unlawfully Occupying Erven 145, 152, 156, 418, 3107, Phillipi \& Portion 0 Farm 597, Cape Rd; Copper Moon Trading 203 (Pty) Ltd v Persons whose Identities are to the Applicant Unknown and who are Unlawfully Occupy Remainder Erf 149, Phillipi, Cape Town 20182 SA 228 (WCC)

First National Bank of SA Limited t/a Wesbank $v$ Commissioner for the South African Revenue Services; First National Bank of SA Limited t/a Wesbank v Minister of Finance 20024 SA 768 (CC)

Fose v Minister of Safety and Security 19973 SA 786 (CC)

Government of the Republic of South Africa v Grootboom 20011 SA 46 (CC)

Grobler v Msimanga 20083 All SA 549 (W)

Khosa v Minister of Social Development 20046 SA 505 (CC)

MEC for the Department of Welfare $v$ Kate 20064 SA 478 (SCA)

Minister of Health v Treatment Action Campaign 20025 SA 721 (CC)

Mkontwana v Nelson Mandela Metropolitan Municipality 20051 SA 530 (CC)

Occupiers of 51 Olivia Road, Berea Township and 197 Main Street Johannesburg $v$ City of Johannesburg 20083 SA 208 (CC)

Occupiers of Erven 87 and 88 Berea v De Wet 20175 SA 346 (CC)

Occupiers of Skurweplaas 353 JR v PPC Aggregate Quarries (Pty) Ltd 2012 4 BCLR 382 (CC)

Port Elizabeth Municipality v Various Occupiers 20051 SA 217 (CC)

President of the Republic of South Africa $v$ Modderklip Boerdery (Pty) Ltd 20055 SA 3 (CC)

Residents of Joe Slovo Community, Western Cape $v$ Thubelisha Homes 20103 SA 454 (CC) 
Sailing Queen Investments v The Occupants La Colleen Court 20086 BCLR 666 (W)

\section{Legislation}

Constitution of the Republic of South Africa, 1996

Prevention of Illegal Evictions from and Unlawful Occupation of Land Act 19 of 1998

Promotion of Administrative Justice Act 3 of 2000

\section{List of Abbreviations}

Annu Rev Sociol
Arizona L Rev
CCR
Curr Psychol
DHS
EHP
Harv L Rev
HR L Rev
ICON
J Soc Issues
JLS
OJLS
PELJ
Philos Public Aff
PIE

SAJHR

SALJ

SAPL

SCA

Stell LR

TSAR

UTLJ

Yale J L \& Human
Annual Review of Sociology

Arizona Law Review

Constitutional Court Review

Current Psychology

Department of Human Settlements

Emergency Housing Programme

Harvard Law Review

Human Rights Law Review

International Journal of Constitutional Law

Journal of Social Issues

Journal of Legal Studies

Oxford Journal of Legal Studies

Potchefstroom Electronic Law Journal

Philosophy and Public Affairs

Prevention of Illegal Eviction from and Unlawful Occupation of Land Act 19 of 1998

South African Journal on Human Rights

South African Law Journal

Southern African Public Law

Supreme Court of Appeal

Stellenbosch Law Review

Tydskrif vir die Suid-Afrikaanse Reg

University of Toronto Law Journal

Yale Journal of Law and the Humanities 